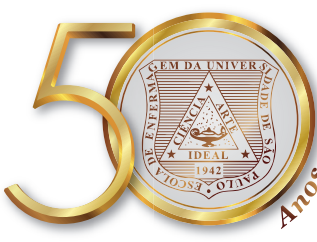

\title{
The phenomenology of Merleau-Ponty in investigations about medication use: constructing a methodological cascade
}

\author{
A fenomenologia de Merleau-Ponty nas investigações sobre o uso de medicamentos: construção \\ de uma cascata metodológica \\ La fenomenología de Merleau-Ponty en las investigaciones sobre el uso de fármacos: construcción \\ de una cascada metodológica
}

Yone de Almeida Nascimento ${ }^{1}$, Agnes Fonseca Ribeiro Filardi ${ }^{1}$, André Joffily Abath ${ }^{2}$, Luciana Diniz Silva ${ }^{3}$, Djenane Ramalho-de-Oliveira ${ }^{1}$

How to cite this article:

Nascimento YA, Filard AFR, Abath AJ, Silva LD, Ramalho-de-Oliveira D. The phenomenology of Merleau-Ponty in investigations about medication use: constructing a methodological cascade. Rev Esc Enferm USP. 2017;51:e03296. DOI: http://dx.doi.org/10.1590/S1980-220X2017017603296

${ }^{1}$ Universidade Federal de Minas

Gerais, Centro de Estudos em Atenção Farmacêutica, Departamento de Farmácia Social, Belo Horizonte, MG, Brazil.

${ }^{2}$ Universidade Federal de Minas Gerais, Departamento de Filosofia, Belo Horizonte, MG, Brazil.

${ }^{3}$ Universidade Federal de Minas Gerais, Faculdade de Medicina, Departamento de Clínica Médica, Belo Horizonte, MG, Brazil.

\begin{abstract}
Merleau-Ponty innovated when giving primacy to the body and perception in his philosophical proposal. Within the field of health, his thinking gives us access to the knowledge gained from the corporeality of individuals with chronic diseases. The objective of this study was to expand the understanding of phenomena associated with the daily use of medication, which includes increasingly complex drug regimes, through the lens of Merleau-Ponty. To this end, we described the research steps anchored in his phenomenological philosophy and structured them in the form of a cascade, beginning with the definition of phenomenology as a new form of epistemology, existence as a paradigm, and the body as a theory. Furthermore, the methodology included the use of existential structures, namely, time, space, relationships with others, and sexuality, connected through the intentional arc to reach an understanding of the phenomenon of medication use.
\end{abstract}

\section{DESCRIPTORS}

Chronic Disease; Drug Utilization; Drugs of Continuous Use; Philosophy Medical; Qualitative Research. 


\section{INTRODUCTION}

Traditionally, in Western philosophy, the body has been neglected, and Merleau-Ponty innovated by giving primacy to the body and to perception in his philosophical proposal ${ }^{(1)}$. Merleau-Ponty considered subjects in the world as bodies in the world and stated that "the body is our general medium for having a world"(2).

Disturbances in the relationship between the body and the world can deeply disrupt existence and, in this direction, an illness and "becoming ill" lead to a different perception of our bodies ${ }^{(1,3)}$. The events of the body that occur in illness "become the events of the day"(2). Thus, the thinking of Merleau-Ponty allows us to access a type of knowledge that originates from the corporeality of individuals living with chronic diseases ${ }^{(3)}$.

Currently, medication use has become the prominent strategy in the search for a cure and/or disease management, requiring the management of increasingly complex drug regimes ${ }^{(4)}$. This technology is introduced in the lives of subjects systematically, and most often, non-democratically. Consequently, patients must reorganize their daily schedules to incorporate them.

Through our experiences caring for patients in use of medications, using an approach that recognizes and values the subjective experience related to their use $e^{(5)}$, the impact of such use on the daily lives of individuals could be observed. Among the various issues that influence patients' decision-making about prescribed medications, emphasis goes to uncertainty about whether to adhere to the instituted therapy, the amount to be ingested, and the correct form of use. These decisions are based on the balance between the benefits and risks of using medications in daily life (4,5-14). $^{(2)}$.

The present study emerged from the researchers' perception that the experiences lived by individuals on chronic use of medications can be understood based on the philosophy of Merleau-Ponty, anchored in corporeality. By understanding their experiences, theories and interventions can be developed to help other patients in the same situation, contributing to the improvement of professional practices in the healthcare context ${ }^{(1,3,16)}$.

However, several authors have stressed that, in the health area, phenomenology-based studies lack philosophical foundation, resulting in ambiguity in objectives, methodology, and results ${ }^{(15-16)}$. Systematizing research methods in the field of phenomenology is a challenge, because information is diluted among the literature and does not always converge. Together, these factors hinder the operationalization of this type of research.

Thus, the present article was idealized as a potential guiding instrument for researchers who have begun down the path of phenomenological research in the health area. The chosen methodology was that of Daly ${ }^{(17)}$, who recommended developing qualitative research by constructing the following cascade: epistemology, paradigm, theory, methodology, methods, and data. Thus, in addition to describing the research, the present article also aimed to clarify essential concepts that traverse the phenomenological approach, as understood by Merleau-Ponty.

\section{THEORETICAL FOUNDATIONS}

\section{Phenomenology as a neW ePistemologicAl APPROACH}

Epistemology, or the theory of knowledge, refers to how researchers obtain knowledge of the reality they wish to understand and how they understand their relationship, as researchers, with what is being researched ${ }^{(17)}$.

Empiricism defends the objective existence of reality, which is external and independent from the researcher, and is based on the use of the scientific method to discover the truth about the world. In idealism, objects in the material world are understood only through rational thought instead of observation, and knowledge is constructed through the process of creating meaning in the mind of researchers. Thus, it presumes that reality is constructed and that it is impossible to separate researcher from the object researched ${ }^{(16-17)}$.

Phenomenology appeared as a proposal to overcome the subject-object scheme, in addition to the realism-idealism opposition that had reigned up to that moment. Merleau-Ponty ${ }^{(2)}$ stated that "the chief gain from phenomenology is to have united extreme subjectivism and extreme objectivism in its notion of the world or of rationality". This proposal can be understood as a philosophical mode of thinking about objects that we believe to experience in the world and that reveal themselves to us, on seeking meaning for that which reveals itself; i.e., phenomenologists are not interested in whether it is the fact "in itself" or the fact that reveals itself, but in the meaning attributed to this phenomenon ${ }^{(18)}$.

A phenomenological approach provides an explanation for the distinction between immediate experience and pre-theoretical liferworld and the theoretical and scientific approach to this experience. Normally, we engage in a pre-reflective dialogue with the world, which occurs in daily activities. In this pre-reflective experience, called natural attitude, we and others accept the world as perceived without questioning, the liferworld, because we do not consider it necessary to analyze situations that are considered obvious ${ }^{(2,18-20)}$. According to Berger and Luckmann ${ }^{(21)}$ natural attitude is the attitude of the consciousness of common sense, which we share with others in normal routines and, for the most part, are pre-reflexive, products of habit. Although the lifeworld is not a creation or a choice of individuals, it permeates their experience of life ${ }^{(22)}$. Merleau-Ponty wished to draw our attention to the meaning of this silent context ${ }^{(19)}$.

Within the realm of the health sciences, people who are undergoing illness possess tacit knowledge, high levels of corporal consciousness and self-monitoring skills, which are not discussed routinely, because they belong to the lifeworld ${ }^{3,19)}$. Phenomenological analysis can help us understand the differences between immediate experience of falling ill and the disease framed by scientific knowledge, of the body experienced by the subject and as an object of scientific investigation $^{(22)}$, and the process of medication use, immersed in the routines of the liferworld ${ }^{(4,11)}$. 


\section{EXISTENCE AS A PARADIGM}

Paradigms refer to universally recognized scientific realizations in a given era, or yet, to the collective opinion of a community of scientists about how science should be conducted, which questions should be asked, and the adequate methods for answering them ${ }^{(17)}$.

According to Merleau-Ponty ${ }^{(2)}$ we are concrete human beings living in a specific time and space and we find meaning in objects that depend on our effective relationship with them. However, essence cannot be separated from existence, the understanding of concepts cannot be separated from the comprehension of the world to which they refer ${ }^{(18,20)}$. Therefore, the Philosophy of Existence, proposed by this philosopher, encompasses corporeality and intersubjectivity in an original manner, and knowledge about human existence becomes fundamental ${ }^{(23)}$. Corporeality refers to how we place ourselves in the world through our bodies ${ }^{(2)}$. Intersubjectivity exposes the issue of human beings living together in a complex relationship called collectivity ${ }^{(23)}$ and includes how humans relate to the world, and the modes in which the world manifests to humans and determines their possibilities ${ }^{(2)}$.

Thus, those who wish to conduct research anchored in the phenomenology proposed by Merleau-Ponty need to understand that this methodology addresses human beings in the world, involved in tradition, history and in the world of other beings ${ }^{(2,20)}$. In sum, "we are in the world and not merely exist in the world"(2).

In the context of medication use, it is important to observe that patients become familiar with the cost/benefit of treatment based on their own experience, but also based on the lifeworld shared with other human beings ${ }^{(12,14)}$.

\section{THE BODY AS A THEORY}

The next step in constructing a qualitative study is choosing a theory, which is a system of ideas that guide researchers in their choice of methods, data analysis, and discussion of results ${ }^{(17)}$. Discussing theories when describing a given phenomenon increases the possibilities of its understanding; however, it is the phenomenon that indicates how and when the theory should be used ${ }^{(20)}$.

According to Merleau-Ponty ${ }^{(2)}$, we live as embodied subjects who experience the world and its essential structures (time, space, relationships with others, and sexuality) through our lived or phenomenal body ${ }^{(15)}$. As beings-inthe-world, we understand the world as a flow of experiences, anchored in the body ${ }^{(24)}$. Thus, it is essential the distinction made by the author between the body object, the physical body of objective science, and the lived body, responsible for experience ${ }^{(1)}$. We apprehend and interact with the world through our lived or phenomenal body, an embodied consciousness, that simultaneously engages with and is engaged by the surrounding world and, for this reason, enables our existential projects ${ }^{(22)}$. Being an embodied subject also implies being situated in the world, affected by social, cultural, political, and historical forces $^{(3,15)}$. Thus: "the body is the vehicle of being in the world, and having a body is, for a living creature, to assemble with a definite environment, to identify oneself with certain projects and be continually committed to them" ${ }^{(2)}$. This embodied experience requires new forms of insertion and relating with the world, which Merleau-Ponty called perception. All the knowledge in our consciousness is first submitted to perceptive experience, which is a bodily experience ${ }^{(19)}$. Matthews ${ }^{(18)}$ was pragmatic when he stated that "this direct, pre-reflective, involvement is perception, which is fundamentally a practical involvement with things. To perceive something is not just to have an idea of it, but to deal with it in some way".

Healthy bodies are transparent and this is the hallmark of health and normal functioning. We do not stop to consider the processes that are taking place in our body during existence and we do not perceive the multiplicity of actions and the expertise required to execute routine activities, such as taking a bath or getting dressed ${ }^{(19)}$. However, in illness, the ease with which these activities are carried out disappears, for our ability is lost. And when we are sick, our attention is drawn to that which is not working well. This is the stage in which the harmony between body object and lived body is upset; a disruption whose meaning goes far beyond the simple mechanical dysfunction of a bodily subsystem, affecting our being-in-the-world ${ }^{(22)}$. Illness is a presence that modifies life, transforming how we experience our body, react, and carry out tasks. For this reason, "Illness is a painful and violent way of revealing the intimately bodily nature of our being" ${ }^{(19)}$.

Medications can cause changes in the body, both positive and negative. Thus, the benefits, such as symptom relief $^{(10,12)}$, disease control ${ }^{(5,14)}$, normalizing deficient endogenous substances ${ }^{(12)}$ and the risks, such as adverse reactions or fear of dependence or tolerance ${ }^{(10)}$ are carefully assessed based on the changes felt in the body ${ }^{(5)}$. Thus, using corporeality, as expressed by Merleau-Ponty, expands our field of understanding regarding phenomena associated with the use of medications.

\section{THE ESSENTIAL STRUCTURES OF HUMAN EXISTENCE}

By promoting changes in our physical and phenomenal bodies, illnesses and medications promote an altered experience of the essential structures of human existence, namely: time, space, relationship with others, and sexuality.

Time is one of the main structures of human existence, and Merleau-Ponty ${ }^{(2)}$ stated that it cannot be considered "an object of our knowledge, but as a dimension of our being." The philosopher was not referring to chronological time, which is measurable, shared, composed of successive moments, and used to structure and guide daily live, but to phenomenological time $e^{(2,17,25)}$.

According to Merleau-Ponty, we experience phenomenological time as a synthesis of transition and through the intuition of permanence. In his words: "the fresh present is the passage of future to present, and of former present to past, and when time begins to move, it moves throughout its whole length," ${ }^{(2)}$ and thus there is only "one single phenomenon of running-off." ${ }^{(2)}$. Therefore, temporality refers to how 
different instants, past, present and future, are co-constituted. According to Merleau-Ponty ${ }^{(2)}$, it is always in the present where we are centered, and from which our decisions start, which are never motiveless, and can always be brought into relationship with our past. We are the ones who find in our conception of the past and present a reason for acting this way and not, and must resort to all our experience, which in the present becomes important for understanding and decision-making ${ }^{(20)}$. Furthermore, on reopening the past, it exists to us as we see it now, and it may have been altered. Similarly, in the future, we may not recognize the present in which we live.

Last, we outline the life phases or stages when we consider as present everything that holds a relationship of meaning with our current occupations, recognizing the connection between time and meaning ${ }^{(2)}$.

A truly disruptive experience is the transformation in how the present, past and future are experienced. There are several alterations in the experience of time described by patients when they are given the news of a severe or debilitating disease, such as a stagnated and expanded present, which compresses the past and shortens the future, as described by Toombs ${ }^{(22)}$ : "If this news is true,' I say to myself, (...) 'I am at once disoriented and reoriented. I know that the past is my past, but it now seems cut adrift, no longer the phase of my life coherently preceding my present and forming the ground of my harmonious passage into the future. 'If this is true,' I think, 'then the future for which I have lived and hoped and planned is suspended, perhaps even closed off forever."

Thus, phenomenological time for individuals who experience a rupture in their health may be experienced as: lack of confidence about their health in the future, a feeling of discontinuity related to the memory of past health and a radical review regarding the best way to use one's time ${ }^{(3,26)}$. This process is based on fundamental temporal forms - the inseparability of the present, past and future. This context remains as the scenario for the experience of individuals, even in the presence of a paralyzed or stagnated present and provokes in the immediate present a chaotic movement among the other temporal forms ${ }^{(22)}$.

The use of medications can cause deep changes in the perception of time, both chronological and phenomenological. It is possible to develop a new perception of time centered on the drug treatment ${ }^{(5)}$, which can even be a dynamic process over time ${ }^{(12)}$. Practical issues, such as maintaining an adequate supply of medications between appointments and visits to the pharmacy ${ }^{(6)}$, organizing administration schedule, which frequently requires changes in daily routines ${ }^{(12)}$, are some examples of issues related to chronological time. However, the experience of a frozen present when waiting for an adequate amount of time to obtain maximum treatment response ${ }^{(12)}$, or the emergence of less aggressive therapies ${ }^{(7)}$ are part of the experience of phenomenological time. Furthermore, medications point to the possibility of experiencing the future ${ }^{(14)}$, but also symbolize the passing of time, as a sign of ageing ${ }^{(5)}$.
Being-in-the-world also means a spatial existence and the phenomenal body is the spatial and temporal center around which the world is organized, the medium through which we exist ${ }^{(2,22)}$. Thus: "far from my body's being for me no more than a fragment of space, there would be no space at all for me if I had no body"(2).

Our experience of space is centered in ourselves, which becomes the reference point for the positioning of all other objects; it is through space guided by the body in the world that we have the dimension of above, below, over or under ${ }^{(2)}$. And the phenomenal space of our bodies is defined by its task and situation ${ }^{(25)}$. We are always placing our experiences either close or far from ourselves, not in terms of measureable distance, but regarding the level of importance we give to them ${ }^{(17-18)}$. According to Merleau-Ponty ${ }^{(2)}$, we inhabit a space of possibilities and find things in terms of the possibilities they offer and, "my body is wherever there is something to be done"(2).

Given that our surrounding space is intimately related to the position of the body, the emergence of a disability that leads to bodily changes inevitably changes our spatial experience. Toombs ${ }^{(22)}$ described the various ways she experienced space and time as an individual with multiple sclerosis when she loses mobility and needs to use a wheelchair.

Still according to Merleau-Ponty the perceived world is only apprehended through orientation, space is on the horizon of all our perceptions and "each of the levels in which we successively live makes its appearance when we cast anchor in some 'setting' which is offered to us"(2).

The use of medications can limit the possibility of experiencing given spaces, as perceived by patients with mental disorders regarding a silent verbal contract imposed by society to accept them, characterizing a form of $\operatorname{control}^{(10)}$. The availability of access to medication in certain geographical regions can also objectively limit the experience of space $^{(11)}$. One of the participants interviewed by Sánchez ${ }^{(11)}$ posited that they lived in a gold cage due to the availability of antiretroviral drugs, which would not have been possible in their country of origin.

On our relationship with others, according to MerleauPonty, we need to rediscover the social world as a permanent field or dimension of existence ${ }^{(2)}$. For Berger and Luckmann ${ }^{(21)}$ we cannot exist in daily life without being continuously in interaction and communication with others and our natural attitude regarding this world corresponds to the natural attitude of others.

In this direction, medications, understood as a symbol constructed from relationships with others, unveil disease or point to the incapacity of individuals to deal with problems without their use, as is expected by society. These situations position individuals as different and can cause stigma ${ }^{(10,12)}$. Thus, they are capable of deeply impacting social, work, and even family relationships ${ }^{(10)}$. Relationships with others, mediated by medications, can also be perceived as coercive, when their use is imposed in exchange for social acceptance ${ }^{(10)}$. But the other can also signify a source of information $^{(10,12,14)}$ or even support ${ }^{(8)}$, influencing behavior regarding the use of medication. 
Sexuality for Merleau-Ponty spreads out through all personal existence and can be conceived as an existential need, in the sense that it is part of the general existence of humans, i.e., indissociable from such existence. Furthermore, "it (sexuality) is the general power, which the psychophysical subject enjoys, of taking root in different settings, of establishing themselves through different experiences, of gaining structures of conduct. It is what causes a subject to have a history"(2). Thus, it can be understood as a certain energy that pulsates and leads us to launch ourselves into life situations, and construct our history in the world, and must not be confused with an exclusively genital factor ${ }^{(2)}$.

Verbeek-Heida and Mathot ${ }^{(12)}$ show us that, for some individuals, feeling well serves as a justification to interrupt medications, however, to others, it is a reason to maintain them. Similarly, Wong and Ussher ${ }^{(14)}$ perceive three forms through which patients contextualize treatment in their lives: as a life-saving resource, as a necessary evil, or as the last resort. Thus, each person constructs their history, making rational decisions that aim to maintain control over life $\mathrm{e}^{(5)}$, obtaining some therapeutic gain, but minimizing adverse effects ${ }^{(10)}$. In this direction, listening to the body is an important part of this process, contributing so that individuals find a comfortable and safe situation based on trial and error ${ }^{(8)}$.

At this point, it is relevant to bring up Merleau-Ponty's ${ }^{(2)}$ discussion about freedom, which according to him, is not absolute. For Matthews ${ }^{(18)}$ human freedom is "an ordinary making of choices in a world we did not choose"; we are always in concrete situations that impose limits to our freedom, especially our past, which does not determine our present actions, but forms the context in which we are inserted.

The use of medication can be inserted in a context of reduced freedom. Patients living with HIV/AIDS report only using medications approved by their physicians, because of concern over interactions that can impact the effect of antiretrovirals ${ }^{(10)}$. Because it demands specific knowledge, physicians can reduce individual empowerment, who becomes dependent on them and the health system. Furthermore, professionals assume that patients must subordinate their other life interests, giving priority to adherence to treatment ${ }^{(14)}$. In this direction, according to Shoemaker and Ramalho-de-Oliveira ${ }^{(5)}$, taking medications regularly and as prescribed puts patients in a passive position, and therefore, medications can be a symbol of dependence.

Merleau-Ponty uses the term intentional arc to describe our relationship with the world, connecting all the essential structures of lived experience in a significant way, which is unique to each individual ${ }^{(3,15)}$. Thus, it produces an existential synthesis, which is a setting of significant articulation between the various sectors of experience. Still, according to Merleau-Ponty ${ }^{(2)}$, this arc is disturbed in the illness process: "the life of consciousness - cognitive life, the life of desire or perceptual life - is sustained by an 'intentional arc' that projects around us our past, our future, our human setting, our physical, ideological, and moral situation, or rather which results in our being situated under all these aspects. It is this intentional arc which brings about the unity of the senses, the unity of the senses and intelligence, the unity of sensibility and motricity. And it is this which extends in the illness"(2).

The effects caused by medication on the body, on social relationships, on an individual's insertion in a given context, on the possibility of living the present fluidly and on the hope of the future, mutually influence each other, also altering the intentional arc. And, in this direction, the use of Merleau-Ponty's theoretical framework can be an important resource to help us understand the phenomenon related to the daily use of medication.

\section{METHODOLOGICAL TRAJECTORY}

\section{ReseARCh SUbJeCtS AND DATA COLLECTION}

In phenomenological research, we must select individuals with the most potential to provide a rich, pertinent and diverse report about the experience in question, i.e. intentional sampling is recommended to select cases that manifest the phenomenon with greater intensity ${ }^{(27-28)}$.

We should also describe the context in which the data were collected to aid readers in understanding how subjects were included in the study, how they provided data and the diversity of the included perspectives ${ }^{(28)}$.

No specifically phenomenological data collection method has yet been developed, but interviews are considered appropriate when researchers wish to describe experiences and understand the meaning of the lived world from the perspective of those interviewed ${ }^{(20)}$. They can be semi-structured, serving as a script built upon broad and flexible themes, which permits participants to talk freely about the experience, and allowing for the inclusion of themes that were not foreseen. The data must be collected up to the point of saturation ${ }^{(11,20,27)}$.

Stelter ${ }^{(24)}$ emphasizes the fact that pre-reflexive knowledge is not directly communicable, requiring an indirect approach. Thus, it is important to be open to detect "what is on the brink of being called into existence for the first time."(24). Thus, we should also seek knowledge exposed through the unsaid, explore issues that are assumed, considered implicit, and that are usually part of common sense. Stelter highlighted that the phenomenon frequently manifests itself not in the form of thoughts or words, but as "a single (often puzzling and very complex) bodily feeling"(24). In this direction, observation is an important data source; however Queiroz et al. ${ }^{(29)}$ warn us that this method only becomes scientific when it is submitted to a systematization, planning, and control process. Thus, all the subjective aspects that could not be apprehended in interviews can be registered in a field diary and interwoven with the participant's speech when transcribing the interview.

The field diary can be used to help with reflexivity or self-reflection, promoting attention to and reflection about the impact of our own history and the links among certain types of knowledge on how we see the participants' history; it also allows readers to assess this influence in the study construction ${ }^{(27)}$. 


\section{DATA ANALYSIS}

Data analysis in phenomenological research takes place through several steps. First, a detailed description of the phenomenon is provided, followed by phenomenological reduction. Then, researchers must search for the essential structure of the phenomenon, i.e., understanding it, and last, communicating it evocatively ${ }^{(20,29)}$.

Description begins by transcribing the interviews. During this phase, it is essential for researchers to immerse themselves in the data, which includes several readings of the transcriptions, carefully listening to the audio recordings, and reviewing the field data. These different incursions lead researchers to understand the data set and how the parts inter-relate ${ }^{(11)}$.

The next step is thematic analysis. This begins with a holistic approach, by reading and re-reading the entire text openly and carefully, with the goal of identifying its meaning. Next, a selective approach is taken, by analyzing the parts, looking for phrases or affirmations that are essential to describe the assessed phenomenon. Last, when researchers identify that the text is full of meaning and themes, they assess the text once more as a whole, but now with a greater understanding than that held in the beginning of the process ${ }^{(20,29)}$.

To escape from the natural attitude and reach the essence of phenomena, which is not obvious at first, phenomenological reduction must be performed ${ }^{(14,17)}$. Also known as epoche or bracketing, this technique implies suspending the facts in themselves, and the beliefs, assumptions, or theories about the phenomenon, considering the experience by itself, thus apprehending the meaning or essence of the phenomenon ${ }^{(18)}$. According to Toombs ${ }^{(22)}$ reduction is a method for engaging in the radical reflection on experience, as it clarifies and renders explicit the theoretical, social, cultural, and professional assumptions that influence our understanding and interpretation of the experienced phenomenon. Finally, it allows us to shift our attention from the experienced object to its modes of appearance ${ }^{(26)}$.
In the search for the essence of the phenomenon, another important methodological aspect, and that can be used to achieve reduction, is the use of imaginative variation, described as mental experimentation in which researchers consciously alter, through their imagination, different aspects of experience, removing or adding aspects to the phenomenon. Thus, researchers imagine all the variations that a phenomenon can undergo until they reach that which could not be suppressed without destroying the phenomenon itself ${ }^{(30)}$.

According to Stelter ${ }^{(24)}$, understanding human behavior requires comprehending the body-anchored, pre-conceptual and pre-reflective experiences of subjects regarding a specific context. Furthermore, it is essential to develop a strategy that can capture this experiential dimension. In this direction, Wilde ${ }^{(15)}$ indicated that the concept of the intentional arc can be applied to phenomenological analysis in the health context. With this statement, the author encourages questions about how the intentional arc can be affected by how patients experience the daily use of medications.

\section{FINAL CONSIDERATIONS}

The use of the phenomenological approach in research requires knowledge about its philosophical foundations, and constructing a methodological cascade aids in the coherent development of studies guided by this approach.

Because it is body-anchored, the phenomenology of Merleau-Ponty can be of great use in research about the daily use of medication, as it can generate deep bodily changes. The analysis of essential existential structures and their connection through the intentional arc is also a useful strategy for understanding this phenomenon.

We hope that this methodological approach can help researchers with their work, contributing to the generation of new knowledge in the health area, especially in relation to medication use.

\section{RESUMO}

Merleau-Ponty foi inovador ao colocar o corpo e a percepção como pontos centrais em sua proposta filosófica. No âmbito saúde, o pensamento desse filósofo permite o acesso ao conhecimento oriundo da corporeidade por parte de pessoas com doenças crônicas. O objetivo deste trabalho é ampliar a compreensão dos fenômenos atrelados ao uso cotidiano de medicamentos, usados em regimes medicamentosos cada vez mais complexos, por meio do pensamento do filósofo. Para tanto, descrevemos os passos de uma pesquisa ancorada na fenomenologia de Merleau-Ponty e estruturada na forma de uma cascata que se inicia pela definição da fenomenologia como uma nova epistemologia, a existência como paradigma e o corpo como teoria. Ainda, como metodologia, propomos o uso das estruturas da existência, o tempo, o espaço, a relação com o outro e a sexualidade, conectadas por meio do arco intencional para se alcançar a compreensão do fenômeno do uso de medicamentos.

\section{DESCRITORES}

Doença Crônica; Uso de Medicamentos; Medicamentos de Uso Contínuo; Filosofia Médica; Pesquisa Qualitativa.

\section{RESUMEN}

Merleau-Ponty fue innovador al colocar el cuerpo y la percepción como puntos centrales en su propuesta filosófica. En el marco salud, el pensamiento de ese filósofo permite el acceso al conocimiento proveniente de la corporeidad por parte de personas con enfermedades crónicas. El objetivo de este trabajo es ampliar la comprensión de los fenómenos vinculados con el uso cotidiano de fármacos, utilizados en regímenes cada vez más complejos, mediante el pensamiento del filósofo. Para eso, describimos los pasos de una investigación anclada en la fenomenología de Merleau-Ponty y estructurada en la forma de una cascada que se inicia por la definición de la fenomenología como una nueva epistemología, la existencia como paradigma y el cuerpo como teoría. Como metodología, proponemos asimismo el uso de las estructuras de la existencia, el tiempo, el espacio, la relación con el otro y la sexualidad, conectadas por medio del arco intencional para alcanzarse la comprensión del fenómeno del uso de medicamentos.

\section{DESCRIPTORES}

Enfermedad Crónica; Utilización de Medicamentos; Medicamentos de Uso Continuo; Filosofía Médica; Investigación Cualitativa. 


\section{REFERENCES}

1. Thomas SP. Through the lens of Merleau-Ponty: advancing the phenomenological approach to nursing research. Nurs Philos. 2005;6(1):63-76.

2. Merleau-Ponty, M. Fenomenologia da percepção. 4ª ed. São Paulo: Martins Fontes; 2011.

3. Wilde MH. Embodied knowledge in chronic illness and injury. Nurs Inq. 2003;10(3):170-6.

4. Haslbeck JW, Schaeffer D. Routines in medication management: the perspective of people with chronic conditions. Chronic IIIn. 2009;5(3):184-96. DOI: 10.1177/1742395309339873

5. Shoemaker SJ, Ramalho de Oliveira D. Understanding the meaning of medications for patients: the medication experience. Pharm World Sci. 2008;30(1):86-91. DOI: 10.1007/s11096-007-9148-5

6. Ellis RJB, Welch JL. Medication-taking behaviours in chronic kidney disease with multiple chronic conditions: a meta-ethnographic synthesis of qualitative. J Clin Nurs. 2017;26(5-6):586-98.

7. Ganzella M, Zago MMF. A experiência dos talassêmicos adultos ao tratamento. Rev Latino Am Enfermagem [Internet]. 2011 [citado 2012 jan. 18];19(4): Disponível em: http://www.scielo.br/pdf/rlae/v19n4/pt_16.pdf

8. Ingadottir B, Halldorsdottir S. To discipline a "dog": the essential structure of mastering diabetes. Qual Health Res. 2008;18(5):606-18. DOI: $10.1177 / 1049732308316346$

9. McSharry J, McGowan L, Farmer AJ, French DP. Perceptions and experiences of taking oral medications for the treatment of Type 2 diabetes mellitus: a systematic review and meta-synthesis of qualitative studies. Diabet Med. 2016;33(10):1330-8. DOI: 10.1111/dme.13152

10. Pound P, Britten N, Morgan M, Yardley L, Pope C, Daker-White G, et al. Resisting medicines: a synthesis of qualitative studies of medicine taking. Soc Sci Med. 2005; 61(1):133-55. DOI:10.1016/j.socscimed.2004.11.063

11. Sánchez LD. Medication experiences of Hispanic people living with HIV/AIDS. Inov Pharm [Internet]. 2010 [cited 2013 Nov 28];1(1). Available from: http://pubs.lib.umn.edu/innovations/vol1/iss1/6/

12. Verbeek-Heida PM, Mathot EF. Better safe than sorry - why patients prefer to stop using selective serotonin reuptake inhibitor (SSRI) antidepressants but are afraid to do so: results of a qualitative study. Chronic Illn. 2006;2(2):133-42 DOI: 10.1179/174592006X111003

13. Webster A, Douglas C, Lewis G. Making sense of medicines: 'Lay Pharmacology' and narratives of safety and efficacy. Sci Cult. 2009;18(2):233-47.

14. Wong WKT, Ussher J. How do subjectively-constructed meanings ascribed to anti-HIV treatments affect treatment-adherent practice? Qual Health Res. 2008;18(4):458-68.

15. Wilde MH. Why embodiment now? Adv Nurs Sci. 1999;22(2):25-38.

16. Willis JW. History and context of paradigm development. In: Foundations of Qualitative Research: interpretive and critical approaches. Thousand Oaks: SAGE; 2007. p. 27-66.

17. Daly KJ. Qualitative methods for family studies \& human development. Thousand Oaks: SAGE; 2007.

18. Matthews E. Compreender Merleau-Ponty. $2^{\text {a }}$ ed. Petrópolis: Vozes; 2011.

19. Carel H. Phenomenology and its application in medicine. Theor Med Bioeth. 2011;32(1):33-46. DOI: 10.1007/s11017-010-9161-x

20. Dahlberg K, Drew N, Nyström M. Reflective lifeworld research. Lund: Studentlitteratur; 2001.

21. Berger PL, Luckman TA. Construção social da realidade: tratado de sociologia do conhecimento. $35^{\text {a }}$ ed. Petrópolis: Vozes; 2013.

22. Toombs SK. Handbook of phenomenology and medicine. Dordrecht: Springer; 2001.

23. Merleau-Ponty. The philosophy of existence. In: Stewart J. The debate between Sartre and Merleau-Ponty. Evaston: Northwestern University; 1998. p. 492-503.

24. Stelter R. The transformation of body experience into language. J Phenomenol Psychol. 2000;31(1):63-77.

25. Todres L, Wheeler S. The complementarity of phenomenology, hermeneutics and existentialism as a philosophical perspective for nursing research. Int J Nurs Stud. 2001;38(1):1-8.

26. Carel H. Phenomenology as a resource for patients. J Med Philos. 2012;37(2):96-113. DOI: 10.1093/jmp/jhs008

27. Morrow SL. Quality and trustworthiness in qualitative research in counseling psychology. J Couns Psychol. 2005;52(2):250-60.

28. Tong A, Sainsbury P, Craig J. Consolidated criteria for reporting qualitative research (COREQ): a 32 -item checklist for interviews and focus groups. Int J Qual Health Care. 2007;19(6):349-57.

29. Queiroz DT, Vall J, Souza AMA, Vieira NFC. Observação participante na pesquisa qualitativa: conceitos e aplicações na área da saúde. Rev Enferm UERJ [Internet]. 2007 [citado 2015 set. 08];15(2):276-83. Disponível em: http://www.facenf.uerj.br/v15n2/v15n2a19.pdf

30. Corrêa AK. Fenomenologia: uma alternativa para pesquisa em enfermagem. Rev Latino Am Enfermagem [Internet]. 1997 [citado 2014 set. 16];5(1):83-8. Disponível em: http://www.scielo.br/pdf/rlae/v5n1/v5n1a10.pdf 